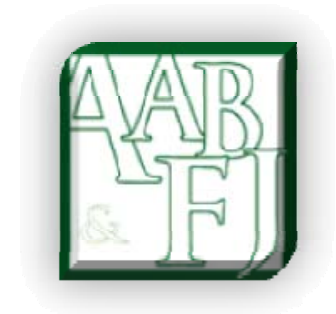

\title{
Editorial Volume 7 Issue 1
}

\author{
Ciorstan Smark ${ }^{1}$, Greg Laing² \& Ron Perrin 3
}

The articles published in this issue of AABFJ cover a variety of discipline areas as well as providing a contrast in methodologies for research. Wild (2013) critiques the political ideologies and practices of the New Public Management model in New Zealand and suggests as an alternative the 'Wellbeing of Communities' reporting and accountability framework devised for by an indigenous New Zealand Māori educational institution. Brimble, Vyvyan and $\mathrm{Ng}$ (2013) consider whether people holding strong religious beliefs are more likely than others to invest in socially responsible investment alternatives.

Probohudono, Tower and Rusmin (2013) consider how voluntary risk disclosures varied across South East Asian countries' manufacturing companies during the global financial crisis. Abdullatif (2013) considers how audit firms in Jordan deal with different classes of fraud risk factors in their audit clients and which factors the auditors consider to be the most important. Naidu and Patel (2013) compare a quantitative and a qualitative model for detecting earnings management applied to two state-owned and two private entities in Fiji.

Charoenrat and Harvie (2013) examine some factors contributing to the relatively poor efficiency performance of small and medium sized Thai manufacturing enterprises. Oliveira, Rodrigues and Craig (2013) provide a technical note giving an overview of corporate risk-related disclosures in Portugal

\section{References}

Abdullatif, Modar, Fraud Risk Factors and Audit Programme Modifications: Evidence from Jordan, Australasian Accounting Business and Finance Journal, 7(1), 2013, 59-77. Available at:http://ro.uow.edu.au/aabfj/vol7/iss1/5

Brimble, Mark; Vyvyan, Victoria; and Ng, Chew, Belief and Investing: Preferences and Attitudes of the Faithful, Australasian Accounting Business and Finance Journal, 7(1), 2013, 23-41. Available at:http://ro.uow.edu.au/aabfj/vol7/iss1/3

\footnotetext{
${ }^{1}$ University of Wollongong, Australia

${ }^{2}$ University of the Sunshine Coast, Australia GLaing@usc.edu.au

${ }^{3}$ University of Wollongong, Australia
} 
Charoenrat, Teerawat and Harvie, Charles, Technical Efficiency of Thai Manufacturing SMEs: A Stochastic Frontier Analysis, Australasian Accounting Business and Finance Journal, 7(1), 2013, 99-121.

Available at:http://ro.uow.edu.au/aabfj/vol7/iss1/7

Naidu, Dharmendra and Patel, Arvind, A Comparison of Qualitative and Quantitative Methods of Detecting Earnings Management: Evidence from two Fijian Private and two Fijian State-owned Entities, Australasian Accounting Business and Finance Journal, 7(1), 2013, 79-98.

Available at:http://ro.uow.edu.au/aabfj/vol7/iss1/6

Probohudono, Agung Nur; Tower, Greg; and Rusmin, Rusmin, Diversity in Risk Communication, Australasian Accounting Business and Finance Journal, 7(1), 2013, 43-58.

Available at:http://ro.uow.edu.au/aabfj/vol7/iss1/4

Rodrigues, Lúcia Lima; Oliveira, Jonas; and Craig, Russell, Technical Note: Company Risk-related Disclosures in a Code Law Country: A Synopsis, Australasian Accounting Business and Finance Journal, 7(1), 2013, 123-130.

Available at:http://ro.uow.edu.au/aabfj/vol7/iss1/8

Wild, Susan, Accounting for Heritage, Cultural and Community Assets - Alternative Metrics from a New Zealand Māori Educational Institution, Australasian Accounting Business and Finance Journal, 7(1), 2013, 3-22.

Available at:http://ro.uow.edu.au/aabfj/vol7/iss1/2 